\title{
Plant biotechnology: use of tissue culture techniques in species Boerhavia paniculata Rich and Crinum americanum $L$ as alternative for the production of new drugs in vitro
}

\author{
Silvana Araújo*, Alberdan Santos \\ From 5th Congress of the Brazilian Biotechnology Society (SBBIOTEC) \\ Florianópolis, Brazil. 10-14 November 2013
}

\section{Background}

Crinum americanum $L$. popularly known as lily is an ornamental plant that belongs to the family Amaryllidaceae alkaloids presenting with anti-inflammatory, antimicrobial and inhibition acetilcolinisterase. The species Boerhavia paniculata Rich is a plant from the family Nyctaginaceae popularly known as "Pega Pinto" that produces isoflavones that have action antiinflmatórias urinary tract and with its concentration in the roots. Aimed at the production and accumulation of these substances in vitro, this work aimed to study the induction of roots of the species Boerhavia paniculata Rich and callus induction of the species Crinum americanum $L$ through the techniques of tissue culture protocols developed cell culture for production of these metabolites and evaluate the qualitative HPTLC by these cells $[1,2,5]$.

\section{Methods}

For callus induction species Crinum americanum $L$ bulbs explants were cultured on MS medium supplemented with $3 \%$ sucrose, $0.8 \%$ agar, $\mathrm{pH}$ adjusted to 5.8 and 2.26 $\mu \mathrm{M}$ of 2,4-D. The flasks were kept in a chamber (BOD Eletrolab) for 30 days in the dark at $24^{\circ} \mathrm{C}$, where after this period subcultures were performed in mesams conditions, totaling three subcultures. Boerhavia paniculata Rich seed species were germinated on rich medium containing $1.5 \%$ glucose, $0.8 \%$ agar in the counter $28^{\circ} \mathrm{C}$. The roots of seedlings grown in vitro were inoculated in liquid MS medium containing $3 \%$ glucose, $2.46 \mu \mathrm{M}$ of IBA and $\mathrm{pH}$ 5.8. The vials were kept in partial light at a temperature of $28^{\circ} \mathrm{C} \pm$ $2^{\circ} \mathrm{C}$. For qualitative analysis of the chemical profile of the

Universidade Federal do Pará, Belém, PA, Brazi samples was evaluated in vitro comparisons by HPTLC with fresh samples to assess the production potential of the metabolites of interest through the visualization of bands in UV irradiation chamber at wavelengths $365-254 \mathrm{~nm}$ and after development reagent specific classes of metabolites: alkaloids and Dragendorff to vanillin sulfuric solution for isoflavone. Each staining bands were obtained possibility of the presence of these substances. They applied approximately $5 \mu \mathrm{L}$ of hexane extracts samples from the chromatoplates Boerhavia paniculata Rich and eluted in $20 \mathrm{~mL}$ of Acetate / Hexane (9:1). For samples Crinum americanum $L 5 \mu \mathrm{L}$ was used and eluted with methanolic extract in a system chloroform/ methanol (4:1), all tests were conducted at a temperature of $25^{\circ} \mathrm{C}$ [2-4].

\section{Results and conclusion}

The results showed that roots of Boerhavia paniculata Rich obtained in vitro showed satisfactory results with IBA $2.46 \mu \mathrm{M}$ for induction of roots. For the species Crinum americanum $L$. callus induction MS medium containing $2.26 \mu \mathrm{M}$ of 2,4-D showed induction potential in these culture conditions. From a qualitative HPTLC chromatographic profile of the samples in vitroBoerhavia paniculata Rich and Crinum americanum L. was possible to assert that the objective was achieved, where the plates containing the spots observed at $365-254 \mathrm{~nm}$ and after development, suggest the presence of possible chemical constituents of the class of alkaloids and isoflavonoids.

\section{Acknowledgements}

Amazon Foundation for Research Support Para, FAPESPA

National Council for Scientific and Technological Development, CNPq Coordination of Improvement of Higher Education Personnel, CAPES 


\section{References}

1. Awasthi LP, Verma HN: Boerhaavia diffusa - A Wild Herb with Potent Biological and Antimicrobial Properties. Asian-agrihistory 2006, 10(1):55-68.

2. Berkov S, Codina C, Viladomat F, Bastida J: Alkaloids from Galanthusnivalis. Phytochemistry 2007, 68:1791-1798.

3. Bhojwani SS, Razdan MK: In Plant Tissue Culture - Theory and Practice. Volume 3. Delhi: 1996. Springer; 1996:39-62.

4. Chen SH, Wu MJ: In A Taxonomical Study of the Genus Boerhavia (Nyctaginaceae) in Taiwan. Volume 52. Taiwania; 2007:(4):332-342. 5. Noirfalise A, Mee GJ: Chromatogr 31:594, 196.

doi:10.1186/1753-6561-8-S4-P243

Cite this article as: Araújo and Santos: Plant biotechnology: use of tissue culture techniques in species Boerhavia paniculata Rich and Crinum americanum $L$ as alternative for the production of new drugs in vitro. BMC Proceedings 2014 8(Suppl 4):P243.

\section{Submit your next manuscript to BioMed Central} and take full advantage of:

- Convenient online submission

- Thorough peer review

- No space constraints or color figure charges

- Immediate publication on acceptance

- Inclusion in PubMed, CAS, Scopus and Google Scholar

- Research which is freely available for redistribution

Submit your manuscript at www.biomedcentral.com/submit
(Ciomed Central 